\title{
The Religious Practices Teaching Pedagogy of Islamic Education Excellent Teachers
}

\author{
Nur Hanani Hussin \\ Faculty of Education, National University of Malaysia \\ nurhanani.hussin@gmail.com
}

Mohd Aderi Che Noh

Department of Education and Community Wellbeing, Faculty of Education, National University of Malaysia aderi@ukm.my

\section{Ab. Halim Tamuri}

Department of Leadership and Educational Policy, Faculty of Education, National University of Malaysia tamuri67@gmail.com

\author{
Doi:10.5901/mjss.2014.v5n16p239
}

\begin{abstract}
An Islamic Education Excellent Teacher's (IEET) expertise can be assessed through his teaching techniques. An IEET usually possesses strong Pedagogical Content Knowledge. This study was carried out to investigate an IEET's interest and knowledge of pedagogical content in teaching Islamic Education Religious Practices subject. This study used a qualitative approach to the framework of the case study. The subject of the study is a DG 44 graded IEET with 10 years' experience in teaching Islamic Education. The findings show that the IEET applied all three approaches: student-centered, teacher-centered, and resource/material-centered, but mainly applied the student-centered approach. These findings are in accordance with the features of religious teaching which emphasizes on practice and on the practical aspect. In conclusion, the teaching of the IEET utilizes various teaching approaches, methods and techniques in planning the effective teaching of religious practices.
\end{abstract}

Keywords: Pedagogical Content Knowledge, Pedagogical Knowledge, Excellent Teacher, Islamic Education, Teaching Approaches

\section{Introduction}

IbnuKhaldun (2000) menyatakan profesion sebagai guru adalah satu keahlian, apabila seseorang guru menguasai pengetahuan kandungan dengan baik, guru tersebut akan memahami semua prinsip dasar ilmu tersebut.

The study on effective teaching by excellent teachers had been widely discussed by (Smith 2005), Mohd Kassim (2010), Ahmad Yunus (2011), Creasy et al. (2011), Ab. Halim (2012), Kamarul Azmi (2012), Nur Hanani et al. (2012), Van Driel \& Berry (2012) and Caspersen (2013). The teaching methods of an excellent teacher is usually closely related to the practice of teaching, specifically in relation to the Pedagogical Content Knowledge, that is, "how to teach specific content in specific contexts" which is a key competency to be mastered by a teacher (Mohd Sani, 2006; Mohd Kassim, 2010; Caspersen, 2013), in producing quality teaching (Mellado et al., 1998; Darling-Hammond \& Baratz-Snowden, 2005; Hill et al., 2008; Schneider \& Plasman, 2011). Pedagogical Content Knowledge (PCK) is knowledge which is unique to the teacher combining pedagogical knowledge and content knowledge (Shulman, 1986 \& 1987). These two factors' intergration helps teachers to understand how teaching is planned and delivered taking into account the diversity of students and involving them in the most optimal manner (Shulman, 1987; Ibnu Khaldun, 2000; E. Shoval et al. 2011; Creasy et al., 2011). Ibnu Khaldun (2000) states that the teaching profession is a mastery, when a teacher masters content knowledge, that teacher will understand all the basic principles of that particular discipline. The teacher can then elaborate and expand his teaching delivery in the best possible manner (Mohd Izham, 2010; Mohd Aderi, 2011; Ahmad Yunus, 2011; Schneider \& Plasman, 2011). The PCK is what differentiates a teacher in a particular field from an expert in that field (Cochran et al., 1993).

According to Million and Graham (2000), amongst the elements of effective teaching are (a) clear delivery (b) 
variety of techniques (c) task completion and (d) ability to drive the teaching process. Excellent teachers are able to provide meaningful teaching to the students, and usually possess indepth knowledge in general and specific pedagogy, have knowledge on how a particular subject is to be taught, able to deliver the material clearly so that it is easily understood and hold the students' attention (Ahmad Rafaai, 2011). There is no single teaching technique used for all education purposes, or all knowledge and subjects, all levels of development, the levels of teaching, maturity and alertness; for all teachers and educators; and for all circumstances and environment relating to the teaching process (alSyaibani, 1975). Teaching will be more effective if various strategies, approaches, methods and techniques are used when teaching religious practices. The approaches, methods and techniques used are components of teaching and are closely related to one another (Norhashimi, 2005). According to Mohd Aderi (2011) the combination of various teaching activities involving strategies, approaches, methods and techniques will lead to effective teaching.

\section{Problem Statement}

Previous studies on the profesionalism of teachers of Islamic Education in particular, amongst them by Kamaruzzaman et al. (2003) have found that the elements of teaching practice which obtained a large percentage of low and moderate accomplishment, are the involvement of students, response to students, examples of contents, teaching materials and resources and the implementation of content activities. Further, a study by Ab. Halim et al. (2004) on Islamic Education teachers (IET), show that the methods of lecturing or class are the most popular mode of teaching used in the classrooms. The study by Ab. Halim et al. (2006) shows that out of 717 IET, about $81.3 \%$ per cent had never used video/CD, 82.7\% never utilised the LCD, 85\% had not used Islamic education software and $92.4 \%$ had never accessed the web during learning and teaching of Islamic Education when educators should rightly be skilled in communciation, accessing information, and should learn using various technologies that can be adapted within the teaching profession (Mohd Izham \& Norazah, 2007). Islamic Education teachers are often enslaved by the heavy curriculum content of the subject and limited teaching time (Mohd Aderi, 2011).

Whereas the study conducted by Kamarul Azmi (2010) and Ahmad Yunus (2011) showed that IEET using the teacher-centered teaching approach, are more than those using the student- centered approach. This is contrary to the education theory which states that an excellent teacher's strategy heavily emphasizes a variety of methods of Teaching and Learning and student-centered approach (Esah, 2004). Each of the IEETs studied were more at ease with using the teacher-centered teaching, compared to student-centered, and also possess own unique skills in the use of teaching aids. Four out of eight IEETs studied had Information, Technology and Communication skills and were more comfortable using the internet, audio and video resources, and the website, when teaching aqidah (faith) (Ahmad Yunus, 2011).

The question is, would the same situation, i.e., teacher-centered teaching occurs in other IEET's teaching of religious practices in school? Whereas, in fact the teaching of religious practices focuses on understanding, appreciation and practice and a variety of teaching methods (Ministry of Education, 2003). Education in Islam aims to form a student with taqwa (Muhammad Qutb, 1983) who is always worshipping Allah the Almighty (al-Zaariyyat 51:56) and obeys the teaching of Islam (al-Baqarah 2:38). Based on this aim, Islamic education is not merely a transfer of facts to students, but aims to encourage the appreciation of Islamic teachings. A teacher of Islamic studies therefore, must be outstanding, competitive, of high quality, in line with the role of man as a caliph spreading prosperity on Allah the Almighty earth (alBaqarah 2:30) with the characteristic of doing any task to the best of one's ability, and in accordance with the character of 'ahsanutaqwim'.

Excellent quality in the teaching profession is highly demanded in Islam, in line with the recommendations of the Quran (az-Zumar 39:9). The School Inspectorate and Quality Assurance, the agency responsible for the selection of Excellent Teachers under the Excellent Teachers Terms of Reference document (Ministry of Education, 2006) defines an excellent teacher as a teacher who has a high level of knowledge, skills and expertise in the subject, especially in the areas of teaching and learning. Excellent Teachers are also consistently dedicated and motivated in carrying out their duties and responsibilities. This definition is seen via personal traits, knowledge and skills, task results, communication, potential and the contribution as an Excellent Teacher.

According to Berliner (1986) a significant difference can be seen depending on the teacher's level of professionalism; an expert teacher is one who they sometimes provide exemplary performances from which we can learn'. They are usually able to adapt their teaching delivery to the students' ability (Al-Ghazali, 1939: Al-Syaibani, 1975; Ibnu Khaldun, 2000; Mohd Yusuf, 2000; Darling-Hammond \& Baratz Snowden, 2005; Kamarul Azmi, 2010). Pedagogical content knowledge possessed by the IEET is knowledge that is tacit, and not documented for reference, but it is knowledge that is in the minds of individuals which are usually acquired through experience or knowledge that is difficult to translate (Nor Foniza, 2012). In the reseachers' views, if the knowledge possessed is not extracted from those who are 
successful and disseminated, then this implicit and tacit knowledge cannot be shared. Therefore, there is an urgent need for this study to be conducted, in view of the fact that teaching religious practices is an important aspect of Islamic education and is related to the students' faith and morals (Mohd Kamal, 1988; Ab. Halim et al., 2004).

\section{Pedagogical Content Knowledge of Islamic Education Teaching of Religious Practices}

The subject of Islamic Education is divided into various fields such as the Quran, Hadith, Tawhid, Aqidah (Faith), morals, religious practices and so on. This study refers to the teaching of religious practice only. This is because some parts of Islamic knowledge have their own objectives and content and hence they will require different teaching methods. According to Mohd Kassim (2010) it is important for teachers to master knowledge in the subject they teach, as well as how that knowledge is taught (pedagogy) and the belief held during the planning and implementation of teaching. All the three elements need to be utilized by the teacher in the classroom to produce effective teaching and learning (alSyaibani, 1991; Ahmad \& Mohd Farid Hafidz 2008; Mohd Yusuf, 2000; Ibn Khaldun, 2000). Van Driel and Berry (2012) stressed that if the teachers have strong pedagogical content knowledge, they will be able to understand how students learn, or fail to learn and the development of PCK should be concentrated on, to enhance the level of professionalism of a teacher. It is PCK which will distinguish between expert teachers and a specialist in a field (Cochran et al., 1993), and will form the quality of teaching (Smith 2005).

Effective teaching and learning function to produce effective learning in the classroom. Shulman (1986) had developed a new framework for teacher education by introducing the concept of pedagogical content knowledge (PCK). Ideas proposed by Shulman (1986) had been developed in the "Knowledge Growth in Teaching" project as a model for a broader perspective to understand the process of teaching and learning. Pedagogical Content Knowledge is where teachers need to psychologize a lesson's content clearly to students (Smith, 2005), which covers the knowledge of the subject's content, pedagogical knowledge of the subject, knowledge of the students' characteristics, the teacher's beliefs on the features of the subject and approaches to teaching, to produce effective teaching. In fact, Islamic scholars such as Al-Ghazali (1939) in Ihya 'Ulumuddin had discussed in depth how effective education require a systematic, organized, orderly and gradual process of teaching, according to the level of student ability. Ibn Khaldun (2000) have also stated that the porecess of teaching requires teaching skill or expertise, and even al-Syaibani (1991) asserted that teaching must take into account the students' willingness, ability and individual differences in the classroom. Therefore, Pedagogical Content Knowledge is not something strange in Islamic Education.

Among the objectives of Islamic education syllabus is to strengthen and enhance religious worship and practices obligatory for individual (fardhu 'ain) and understanding the obligation for the community (fardhu kifayah) as a compulsory obligation of Muslims to contribute towards the development of life in this world and hereafter (Ministry of Education, 2003). The Islamic Education topics at the lower secondary level is the concept of individual duty and community duty, and its implications for individuals, communities and the country, and also the concept of purification, istinja' (cleaning oneself with water), ablution, bathing, tayamum (the Islamic act of dry ablution using sand or dust), cleansing and its benefits, compulsory prayers, Friday prayers, rawatib (extra non obligatory prayers), tahhiyatul masjid prayers, jama' and qasar prayers (consolidation and shortening of prayers), Eid 'Fitr and' Eid al-Adha prayers, fasting and the appreciation of Ramadan, tithe being zakat fitrah and on assets, prayers when sick and procedures, night prayers and management of the deceased, all are part of the syllabus at lower secondary level. While at the upper secondary level, the syllabus focuses on the content of the hajj and umrah, slaughter, sacrifice and aqiqah (sacrifice of an animal on the occasion of a child's birth). Mua'amalat principles of sale, lease, mortgage, and company and shares, marriage, conjugal responsibilities, family problems and solution (divorce, ruju', 'iddah, nusyuz, fasakh, khulu', zihar, li'an and poligamy) and parenting skills, family statutes, current issues relating to adoption and hadanah (custody) are contained in the KBSM Islamic Studies syllabus for upper secondary education (Ministry of Education, 2003).

The content of the syllabus is built to achieve the goals of Islamic Education that is to produce Mulisms who have knowledge, faith, charismatic, devout, civilized and of high morals based on the Quran and the Sunnah, as a servant of Allah the Almighty, being Allah the Almighty devout caliph and contributing to the civilization of the nation (Ministry of Education, 2003). Ab. Halim et al. (2004) stated that the formation of an integrated curriculum will not be complete and perfect if the methods of teaching and learning are not emphasized. According to Adnan (2002) the teaching of religious practice is very important in Islamic Education for Muslims as the act of religious practices are carried out all the times and the entire life of a Muslim is considered worship, including actions, thoughts and feelings (Muhammad Qutb, 1983). According to Adnan (2002) also, immersion in worship will develop good character in Muslims as worship is a "long term process of training to mould a noble and moral individual in line with the Quran which explains that the relationship between religious practices with the pillars of faith, amongst them prayer and tithe, and believing in the day of judgement 
(al-Naml 27:3), and fasting, makes someone more devout (al-Baqarah 2:183), and religious practices become a contributing factors to a successful Believer who will inherit heaven (al-Mukminun 23:1-11). Allah urges the Believers to do good, to be responsible and accountable and always under Allah the Almighty observation (at-Tawbah 9:105) and always pursuing to do a good deed (Al-Baqarah 2:148; Al-Anbiya 21:73).

Among the methods that can be used for effective teaching and learning of religious practice subject is storytelling, discussions, simulations, library research, writing articles, field trips, brainstorming, writing scrapbooks, demonstrations and forecasting future events (Ministry of Education, 2003), a visit with the students to the mosque, prayer room, religious institutions or visting renowned religious leaders, celebrating major religious festivals, storytelling, question and answer, problem based learning, revision, practical, demonstrations, acting, and role playing (Muhammad Salih, 1980; Ghazali, 2001). Among the methods that can be utilized in teaching are memorization and understanding, demonstrations, doing practical, simulation, sociodramatic play, role play and discussion (Ab. Halim et al., 2004; Kamarul Azmi \& Ab. Halim, 2012). With regard to techniques, Ahmad (2004) stated that it is the teachers' skills and behaviors in the organization and implementation of teaching methods in any teaching and learning activity. It is sub units which are contained in a particular method; for instance, there are many techniques of asking questions, and the Islamic Studies teacher may either put the question to all students, or randomly during the religious teaching (Norhashimi, 2005). In addition, Islamic Education teachers must be good role models to the students and and always pay attention to students when teaching (Muhammad Salih, 1980; Muhammad Qutb, 1983). Diversity of methods and techniques is necessary to attract the interest of students, retain their attention and arouse curiosity so that learning objectives are achieved.

\section{Objectives and Research Questions}

Based on the background discussion of the research, this study is carried out to achieve the following objectives:

1. Exploring the pedagogy of the research's participants in the teaching of religious practice subject in Islamic Education.

\subsection{Research questions}

1. What is the pedagogy of the research's participants in the teaching of religious practice subject in Islamic Education?

\section{Methodology}

This study used a qualitative approach using a case study framework. The data was collected via interviews, observations and document analysis. Qualitative methods were used for this study as it is very appropriate to review a case in depth and comprehensively (Slavin, 1992) and to gather substantial information about a case. In addition, qualitative methods can provide an opportunity for researchers to observe and examine the IEET's state of knowledge on students in a real environment (Merriam, 1998). Researchers will find information on what is actually happening in the classroom. As the study main tool, the researcher will provide a better understanding and meaning to what is observed (Marohaini, 2001). The selection of sampling was applied the purposive sampling method of Miles \& Huberman (1994). This means that the respondents should be selected and identified in advance so that he can provide appropriate and adequate information. An Excellent Teacher of Islamic Education with the grade of DG44 was selected for this study. The selection was based on input received from the District Education Office and five other IEETs. This teacher has met the criteria set out in this research, namely i) teaches Form Four religious practices subject ii) carries out innovation in teaching religious practices in Islamic Education and iii) has a deep interest in religious practices teaching. Researchers used NVivo 8.0 to organize research data and build the teaching model of research participants.

\section{Research Findings}

The subject of this study is Ustazahs Soleha (not her real name), recognised as an Excellent Teacher of Islamic Education at the age of 29 years old. There are several things that make this case unique and interesting. First, Ustazahs Soleha always strive to excel. Second, she was educated by the family in excellence, all nine of her siblings are teachers and two of her sisters are also Excellent Teachers. Third, she seeks to carry out innovation in the teaching of religious practices. Fourth, Ustazahs Soleha holds a Bachelor of Science in Islamic Education and pursued her studies to Masters in Islamic Education. All four of these things formed the background and shaped her life. The subject of this study was 
also appointed as School Discipline Secretary and Lead Trainer for District Islamic Education in the state where she was assigned.

The researcher found that Ustazahs Soleha has a keen interest in the teaching of religious practices subject. She set out details on the topic of Tithe of Wealth, a challenging topic to be taught, and in fact had determined that the teaching of the topic of Animal Slaughter must be done in practice, as she said:

For me the most interesting thing to me, is religious practice, as I feel I understand it (US TB1/23).

It's so interesting to teach the topic of religious practice. It is in our minds and we do it daily. I really like it. (US TB1/27).

I really like the topic on Tithe of Wealth, as it is very challenging and I want to make them understand.

For Form 4 subject, I like the topic of Animal Slaughter, as it can be done practically (US TB1/31).

When asked by the researcher what if the students do not understand her instructional delivery, she explained that she will be motivated and try to think of other ways to teach. Her answer reflects her character as an excellent teacher who is always thinking of various ways and technique in her teaching. What she spoke on is already implemented in teaching (US OB1).

\section{Feel motivated if students don't understand (US TB2/62)}

Enthusiastic to think of new methods so that the students will understand (US TB2/66)

Based on the three methods of data collection, i.e. interview, observation and document analysis, the teaching of religious practices carried out by Ustazahs Solehah applied all three approaches being teacher-centered, studentcentered and resource-centered. However student-centered appears to be more dominant in her teaching. She had stressed six times that the teaching of religious practices must be done in practice and not in theory (US TB1/US TB2/US TB3). She also gives assignments to her students based on their level of competence, folios for advanced classes and modules for the last classes.

From the interview carried out, Ustazahs Solehah earnestly explained that she encouraged her students to take notes via mind maps (US TB1/13). She also stated that using mind maps able to change the perception of students on the subject of Islamic Education so that it can be easier to understood and remembered. Some of the other studentcentered methods which she applied, based on observation and interview are individual presentation (US OB1/30:12), group discussion and presentation (US OB 1/38:15), intensive revision (US OB1 R/33:35), simulation, recitals musyafahah in prayer (US TB1/129), field trips (US TB1/213), zikr therapy and recitation of asmaulhusna (US TB1/157; US TB2/ 7; US AD1), practicing the repentance prayer (US TB1/154) and religious camps (US TB1/214). The teaching of religious practice based on resources/materials were using nasyid (religious music) method (US OB1/6:40), using powerpoint software (US TB1/132), using the model of the Ka'abah (the Sacred House or Baytu I-Haram) (US AD2), and Sai'e model (Safa-Marwah) (US AD3). Ustazahs Soleha also utilized the ICT such as facebook and email to contact her students and answer their queries after school hours. The teacher-centered teaching using classroom methods (US OB 1/7:52) applied the techniques of questions and answers (US OB1/10:05), using mnemonics to memorise the pillars of hajj, that is, intention, wuquf, tawaf, sai'e, shaving and proper rituals (nina went to school by taxi) (US OB 1/42:17). An action plan called the Therapy Methods of Zikir and repentance prayer (US TB2/8) was drafted and implemented by Ustazahs Soleha especially for the students of the last class, which is the 12th class. The researcher found that she is very commited in drawing up the framework of delivering her knowledge to her students.

A model of Ustazah Soleha's teaching methods was built based on the research's findings. Diagram 1.0 below shows the implementation of the teaching of religious practices by her using three approaches, which are (i) material/resource-centered involving models, mind maps, modules, folio and ICT and (ii) teacher-centered using classroom methods, instuction and key words and (iii) student-centered using practical methods, games, field trips, intensive revision, repentance prayers, mind maps, group presentation, teamwork, memorization/recitation, questions and answers, religious camps, musyafahah, zikir therapy, individual presentation and simulation. 


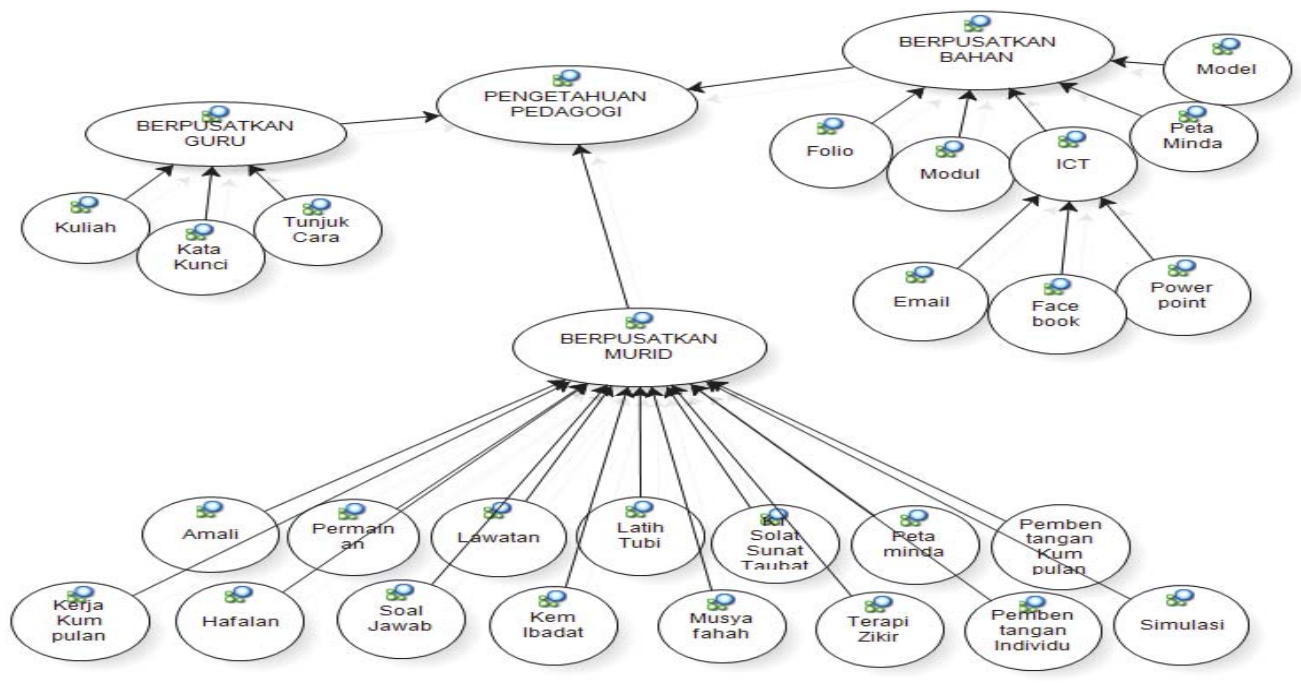

Diagram 1.0: Pedagogical Models of Ustazah Soleha's Religious Practices Teaching Method

Translation of the diagram

\begin{tabular}{|l|l|l|}
\hline Material/resource-centered & Teacher-centered & Student-centered \\
Models & Classroom methods & Practical methods \\
Mind maps & Key words & Games \\
ICT & Instuction & Field trips \\
Modules & Intensive revision \\
Folio & Repentance prayers \\
& & Mind maps \\
& Group presentation \\
& Teamwork Memorization/Recitation Questions and Answers \\
& Religious camps \\
& Musyafahah \\
& Zikir therapy \\
& Individual presentation \\
& Simulation \\
\hline
\end{tabular}

\section{Conclusion}

It is clear that based on the research findings, an IEET's teaching method of religious practice subject were more emphasis in all three approaches centering on students, teachers and materials. Howevwe, the student-centered approach is seen to be more dominant compared to the teacher-centered or resource-centered approaches. This is encouraged by the belief of the teacher that the teaching of religious practice must be done in practice as opposed to in theory. In actual fact, the pedagogical knowledge of a field will determine the teachers' ability to transfer ideas, information, knowledge skills and guidance to the students in a more organized manner. A teacher who has a firm knowledge of the subject content but fail in the process of delivery may not have the mastery of the best methods to deliver the information and guide the students. Therefore the teaching of religious practice must be implemented by applying various approaches, methods and techniques as appropriate to the student's ability and intellect. This is because, understanding and carrying out religious practice correctly is a manifestation of a servant's faith to the Almighty Creator and will indirectly build strength of spirit, emotion and the character of a Muslim, and produce a generation of Muslims who are truly immersed and appreciative of the religion, begins from the knowledge gained in the classroom. 


\section{Rererences}

Al-Quran al-Karim.

Abdul Fattah Abu Ghuddah. (2009). Rasulullah the Incomparable Teacher: 40 of Rasulullah's Teaching Techniques. Translated by Hj Shuhadak Mahmud. Negeri Sembilan: Al Azhar Media.

Ab. Halim Tamuri, Adnan Yusopp, Kamisah Osman, Shahrin Awaluddin, Zamri Abdul Rahim \& Khadijah Abdul Razak. (2004). Research Report on Effectiveness of Teaching and Learning Methods on the Student's Self Development. Faculty of Education, National University of Malaysia and the Division of Islamic Education and Moral Curriculum, JAPIM: Ministry of Education, Malaysia.

Ab. Halim Tamuri. (2012). Improving the Excellence of Islamic Education Teachers. Working Paper on Hadari Discourse Series 6/2012. November 19, 2012.

Abdul Salam Yusof. (2008). Al-Ghazali (Algazel) and Confucius Effective Educational Ideas. Bangi: UKM Publisher.

Adnan Abd Rashid. (2002). Tarbiyah rabbaniyyah (devine education) and its signficance in the development of husnu'l-khuluq. Muslim Education Quartely, 19: 16-29.

Ahmad Mohd Salleh. (2004). Islamic Education: Philosophy, history and teaching methods. Shah Alam: Fajar Bakti Sdn. Bhd.

Ahmad Mohd Salleh, \& Mohd Farid Hafidz Ahmad. (2008). Islam Religion of Divine: Principles of Islamic Education as Foundation for KPLI \& PPISMP. Shah Alam: Oxford Fajar Sdn. Bhd.

Ahmad Rafaai Ayudin. (2011). Effectiveness of teaching history based on the achievement of teaching aims, readiness to learn, understanding of the concept and historical thinking. Ph.D thesis, National University of Malaysia.

Ahmad Yunus Kasim. (2011). Pedagogical Content Knowledge (PCK) in Teaching of Aqidah of Islamic Education Excellent Teachers: $A$ Case Study. Ph.D thesis, National University of Malaysia.

Al-Bukhari. (1989). Sahih Bukhari. Translation. Kuala Lumpur: Victory Agencie.

Al-Ghazali, Abu Hamid. 1939. Ihya Ulum al-Din. Chapter 1. Mesir: Mutba'ah Mustafa al-Babi al-Halabi.

Al-Syaibani, Omar Muhammad Al Toumy. 1975. Falsafah al-tarbiyyah al-Islamiyyah. Libya: al- Mansyaah al-Syabiyyah li al-nasyr wa altauzi' wa al-'ilam.

Al-Syaibani, Omar Muhammad Al Toumy. 1991. Philosophical of Islamic Education. Shah Alam: Hizbi.

Berliner, D.C. 1986. In pursuit of the expert pedagogue. Educational Researcher, 15(7): 5-13.

Caspersen, J. 2013. The valuation of knowledge and normative reflection in teacher qualification: A comparison of teacher educators, novice and experienced teachers. Teaching and Teacher Education. 30 (Feb):109-119.

Cochran, K.F, De Tuiter, J.A \& King, R.A 1993. Pedagogical Content Knowing: An Integrative Model for Teacher Preparation. Journal of Teacher Education, 44(4), 263-272.

Coombs, B. 2009. Teaching Effectively. Kuala Lumpur: Translation. Institut Terjemahan Negara Malaysia Berhad.

Creasy, J.A, Whipp P.R, \& Jackson, B. 2011. Teachers Pedagogical Content Knowledge and Students' Learning Outcomes in Ball Game Instruction. 7(1): 3-11.

Darling-Hammond, L. \& Baratz-Snowden. 2005. A good teacher in every classroom: Preparing the highly qualified teachers our children deserve. New York: Jossey-Bass.

E. Shoval. R. Talmor \& O. Kayam. 2011. The concept of coherency in teaching: forging an idea from professional literature - a case analysis and a discussion with experts. International Journal of Qualitative Studies in Education 24(4):397-417.

Esah Sulaiman. 2004. Introduction to Pedagogy. Skudai: Universiti Teknologi Malaysia Publisher.

Hafiz al-Suwaid, Muhammad Nur bin Abdullah. 1988. Manhaj Tarbiyah Nabawiyyah li al-Tifl. Kuwait: Muassasah al-Rayyan.

Hapidah Mohamed. 2001. The Thinking of an Excellent Teacher: impact on the teaching performance. Ph.D thesis, National University of Malaysia.

Hill, H.C., D. Loewenberg-Ball \& S.G. Schilling. 2008. Unpacking pedagogical content knowledge: Conceptualizing and measuring teachers' topic-specific of student. Journal for Research in Mathematics Education 39(4):372-400.

Ghazali Darusalam. 2001. Islamic Education Pedagogy. Kuala Lumpur: Utusan Publication \& Distributors.

Ibnu Khaldun. 2000. Muqaddimah Ibnu Khaldun. Kuala Lumpur: Dewan Bahasa and Pustaka.

Kamarul Azmi Jasmi. 2010. Islamic Education Excellent Teacher for Malaysia Secondary Schools: A Case Study. Ph.D thesis, National University of Malaysia.

Kamarul Azmi Jasmi. 2012. Application of Student-centered Approach in Teaching and Learning of Excellent Teachers. Working Paper of Round Table Conference: Preparation of Excellent Teachers. IKIM September 6, 2012.

Kamarul Azmi Jasmi, \& Ab. Halim, Tamuri. 2012. Islamic Studies Teaching and Learning. Skudai: Universiti Teknologi Malaysia.

Kamaruzzaman Abdul Ghani, Khadijah Abdul Razak, \& Mohamed Amin Embi. 2003. Research Report on the Level of Professionalism of Islamic Education and Arabic Language Teachers: A Study of Religious Secondary Schools in Kelantan. Faculty of Education, National University of Malaysia.

Ministry of Education Malaysia. 2003. Explanation of Islamic Education KBSM Syllabus. Kuala Lumpur: Dewan Bahasa and Pustaka.

Ministry of Education Malaysia. 2006. Excellent Teachers Terms of Reference.

Marohaini Yusoff. 2001. Qualitative Research on Field Work Experience. Kuala Lumpur: Universiti of Malaya Publisher.

Mellado, J.K, Blanco, L \& Ruiz, C.1998. A framework for learning to teach science in initial primary education. Journal of Science Teacher Education 9:195-219.

Merriam, S. B. 1998. Qualitative Research and Case Study Application in Education. San Francisco: Jossey-Bass Publishers.

Miles, M. B. \& Huberman, A. M. 1994. Qualitative Data Analysis. 2. Thousand Oak California: Sage Publication. 
Million, S \& Graham, P. 2000. Methods for effective teaching (3 ed.). Boston: Pearson Education.

Mohd Aderi Che Noh. 2011. The practice of teaching recitation of Quran: a review on the perception of teachers at daily secondary schools in Malaysia. Journal of Islamic and Arabic Education, 1(1): 57-72.

Mohd Izham Mohd Hamzah, Ab. Halim Tamuri, Mohd Aderi Che Noh, \& Khadijah Abd Razak. 2010. The professionalism of Islamic Education teachers: A study on perceptions of students at Malaysia secondary school. 15th International Conference on Education, Brunei.

Mohd Izham Mohd Hamzah, \& Norazah Mohd. Nordin. 2007. The role of administrators in the process of planned change: ICT integration and pedagogy in teaching and learning. Third International Seminar on Regional Education, Riau.

Mohd Kamal Hassan. 1988. Education and Development: An intergrated perspective. Kuala Lumpur: Nurin Enterprise.

Mohd Kassim Tusin. 2010. The Self Qualities of Islamic Education Teachers of Sabah Secondary Schools. Ph.D thesis, Universiti Malaysia of Sabah.

Mohammed Sani Ibrahim. 2006. Malaysian Teachers Standard of Compentency. The Teaching Profession (Ed. Norzaini Azman \& Mohammed Sani Ibrahim), Faculty of Education, National University of Malaysia.

Mohd Yusuf Ahmad. 2000. History and Methods of Quran Education. Kuala Lumpur: Universiti of Malaya.

Muhammad Qutb. 1983. Manhaj al-tarbiah al-Islamiyyah. Beirut: Dar al-Syuruq.

Muhammad Salih, Samak. 1980. Islamic Education Knowledge. Kuala Lumpur: Dewan Bahasa and Pustaka.

Nor Foniza Maidin. 2012. Organizational Learning Practice in excellent schools: A case study. Ph.D thesis. Faculty of Education, National University of Malaysia.

Norhashimi Saad. 2005. Islamic Education and Islamic Smart Schools Teaching Methods. Pedagogy across curriculum. Bentong: PTS Professional Publishing Sdn. Bhd.

Nur Hanani Hussin, Ab. Halim Tamuri \& Mohd Aderi Che Noh. 2012. Knowledge of students: a case study of an Islamic Education excellent teacher. International Conference on Education. November 26, 2012. Faculty of Education: University of Malaya.

Schneider, R. M., \& Plasman, K. 2011. Science Teacher Learning Progressions: A Review of Science Teachers' Pedagogical Content Knowledge Development. Review of Educational Research. 81(4): 530-565.

Shulman, L.S. 1986. Those who understand: Knowledge growth in teaching. Educational researcher, 15(2): 4-14.

Shulman, L.S. 1987. Knowledge and teaching: Foundations of the new reform. Harvard educational review, 57(1): 1-23.

Smith, K. 2005. Teacher educators' expertise: what do novice teachers and teacher educators say? Teaching and Teacher Education 21:177-192.

Slavin, R., 1992. Research Method in Education (2nd edition). Boston: Allyn and Bacon.

US TB1 181012: Ustazahs Soleha First Interview on October 18, 2012 at the Computer Lab (55 minutes).

US TB2 051112: Ustazahs Soleha Second Interview on November 5, 2012 at the canteen (53 minutes).

US TB3 081112: Ustazahs Soleha Third Interview on November 8, 2012 at the Moral Room (20 minutes).

US OB1 081112: First Teaching Observation of Ustazahs Soleha on November 8, 2012 at the Moral Room (1 hour 20 minutes).

US AD1 181012: First Document Analysis of Ustazahs Soleha on October 18, 2012 in the Teachers' Room.

US AD2 081112: Second Document Analysis of Ustazahs Soleha on November 8, 2012 in the Moral Room.

US AD3 081112: Third Document Analysis of Ustazahs Soleha on November 8, 2012 in the Moral Room.

Van Driel, J.H., \& Berry, A. 2012. Teacher Professional Development Focusing on Pedagogical Content Knowledge. Educational Researcher, 41(1):26-28. 